\title{
INFLUENCE OF INTEREST, PRICE, PRODUCT QUALITY, PROMOTION, AND BRAND IMAGE ON PURCHASING DECISIONS IN TRAVELOKA APP
}

\author{
Tanggor Sihombing ${ }^{1}$ \\ Pelita Harapan University \\ tanggor.sihombing@uph.edu \\ Dosma Sihombing ${ }^{2}$ \\ Institut Bisnis Nusantara \\ tupak14@gmail.com \\ Received on 31 January 2021 \\ Accepted on 23 June 2021
}

\begin{abstract}
This research was conducted to test and analyze the influence of interest, price, product quality, promotion, and brand image on purchasing decisions. The method used in this research was Structural Equation Modeling (SEM) using the SmartPLS application. The population in this study consisted of Traveloka application users with a total of 137 respondents. The study used purposive sampling with 104 respondents. The test results show that interest variable has a positive and significant effect toward purchasing decisions of Traveloka application users, while the price, product quality, promotion, and the variables of brand image have no significant effect toward users purchasing decisions of Traveloka application.
\end{abstract}

Keywords: Price; Product Quality; Promotion; Brand Image; Interest

\section{INTRODUCTION}

\subsection{Research Background}

The tourism industry in Indonesia is one of the economic driving sectors that is quite a concern because with the diversity of cultures and languages in the country, Indonesia is a magnet for local and international tourists to recognize the diversity and also encourage directly the development of startup applications that facilitate these developments.

Internet users who continue to grow in number are one of the value factors on the development of information channeled to the public and the contribution of several information channels into one medium through the internet. In addition, Based on the results of the Indonesian Polling study in collaboration with the Indonesian Internet Service Providers Association (APJII), the number of internet users in Indonesia grew 10.12 percent therefore the increase of the number of internet users attests to the fact that the internet is not only used as a communication tool, but also supports buying and selling activities (Kompas.com, 2019).

With the increase of internet users, businesses are also utilizing the internet as a marketing medium for their products. The development of the internet also indirectly changed aspects of life including consumer behavior. This includes changes in obtaining information and the need to make decisions in a fast way without limitation of place and time to buy and consume products. Moreover, consumer behavior tends to prefer everything that is practical and easily obtained by conducting online transactions. 
Swasta and Irawan (2008: 145), in Sandy Sinambow and Irvan Trang (2015), argued that consumer decisions are motives or incentives that arise against something where buyers make purchases due to their needs and desires. In determining the right purchasing decision, there are factors that can influence a person's purchasing decision such as one's buying interest, the price offered, product quality, promotion, and brand image of the product / service.

According to Hasan (2013: 173), in Ignatius Danu Ghristian (2016), purchasing interest is the tendency of consumers to buy a brand or take actions related to purchases as measured by the level of likelihood of consumers making purchases. A person's interest in buying a product / service is strongly influenced by the price offered. Kotler and Armstrong (2008: 345), in Denny Kristian and Rita Widayanti (2016), state that the price is the amount of money billed for a product or service, or the amount of value exchanged by customers to get the benefits of owning or using a product or service.

Sundalangi et al. (2014), in Edo Praditya Denniswara (2016), explain that product quality is everything that is offered to the market to get attention, bought, used or consumed that can satisfy consumer desires. Consumer perceptions about a product can describe the quality of the product. Products sold in the market are very influential from promotions conducted by companies. Swastha (1984), in Siti Ainul Hidayah and R.A.E.P. Apriliani (2019), defines promotion as a one-way flow of information or persuasion created to direct a person or organization to actions that create exchanges in marketing. In addition to the purpose of promotion to market a product / service, promotion can also make the brand image of the product / service known or attached to consumers' memories so consumers are interested in buying or even repurchasing, depending on the satisfaction felt by consumers of the product / service.

\subsection{Theoretical Background \\ 1.2.1 Buying decision}

Kotler and Keller (2009), in Astuti and Abdullah (2017) state that purchasing decisions are a stage of consumer evaluation in shaping preferences for brands in a collection of various behaviors.

\subsubsection{Interest}

Kotler and Keller (2012), in Satria and Sidharta (2017), defines buying interest as customer behavior that appears as a response to objects that indicate the customer's desire to make a purchase.

\subsubsection{Price}

Kotler and Keller who were translated by Bob Sabran (2009), in Riyono and Budiharja (2016), stated that price is one of the marketing mix elements that generates revenue, while other elements generate costs.

\subsubsection{Product quality}

Kotler and Keller (2009), in Dewi and Prabowo (2018), defined product quality as the totality of features and characteristics of products or services that depend on their ability to satisfy the needs of consumers, both expressed and implied. 


\subsubsection{Promotion}

Kotler and Keller (2007), in Sari, et. al (2014), stated that promotion is a collection of incentive tools, mostly short-term, designed to stimulate the purchase of certain products or services more quickly by consumers or traders.

\subsubsection{Brand image}

Kotler and Keller (200), in Kurniawati, et. al (2014), defined brand image as perceptions and beliefs held by consumers, as reflected in the associations embedded in consumers' memories, which are always remembered for the first time when they hear slogans about the product or service.

\section{RESEARCH METHODOLOGY}

This research used descriptive and verification research types. The data collection method in this study was survey with a questionnaire instrument. The analysis technique used was SEM or Structural Equation Modeling. This research was conducted on consumers who purchased the travel tickets in Traveloka Platform in meeting their traveling needs with a sample of 104 respondents.

\subsection{Definition of Variable}

Below is the operational definition for each variable used in the study

Table 1. Operational Definitions

\begin{tabular}{|c|c|c|c|}
\hline Variable & Dimension & Indicator & Statement \\
\hline \multirow{4}{*}{$\begin{array}{l}\text { Purchase } \\
\text { Decision } \\
\text { (Hendro and } \\
\text { Hidayat (2018) }\end{array}$} & \multirow[t]{2}{*}{$\begin{array}{l}\text { Choice of } \\
\text { brands }\end{array}$} & \multirow[t]{2}{*}{$\begin{array}{l}\text { Decisions about brand } \\
\text { products }\end{array}$} & $\begin{array}{l}\text { I. I will install the } \\
\text { Traveloka application. }\end{array}$ \\
\hline & & & $\begin{array}{l}\text { 2. I will recommend } \\
\text { Traveloka to others. }\end{array}$ \\
\hline & \multirow[t]{2}{*}{$\begin{array}{l}\text { Choice of } \\
\text { Products }\end{array}$} & $\begin{array}{l}\text { Decision about the time } \\
\text { of purchase }\end{array}$ & $\begin{array}{l}\text { I will make a repurchase } \\
\text { of my traveling needs } \\
\text { through Traveloka because } \\
\text { the quality of the products } \\
\text { offered is reliable. }\end{array}$ \\
\hline & & $\begin{array}{l}\text { Decision about the type } \\
\text { of product }\end{array}$ & $\begin{array}{l}\text { The product offered is one } \\
\text { that suits my traveling } \\
\text { needs. }\end{array}$ \\
\hline \multirow{6}{*}{$\begin{array}{l}\quad \text { Interest } \\
\text { (Widyaningrum, } \\
\text { 2017) }\end{array}$} & \multirow[t]{3}{*}{$\begin{array}{l}\text { Transactional } \\
\text { interest }\end{array}$} & \multirow[t]{2}{*}{$\begin{array}{l}\text { Someone's tendency to } \\
\text { buy product }\end{array}$} & $\begin{array}{l}\text { 1. I am interested in } \\
\text { downloading and installing } \\
\text { the Traveloka application. }\end{array}$ \\
\hline & & & $\begin{array}{l}\text { 2. I am considering } \\
\text { traveling through } \\
\text { Traveloka. }\end{array}$ \\
\hline & & & $\begin{array}{l}\text { 3. I have a desire to travel } \\
\text { through Traveloka. }\end{array}$ \\
\hline & \multirow{2}{*}{$\begin{array}{l}\text { Referential } \\
\text { interest } \\
\text { Referential } \\
\text { interest }\end{array}$} & \multirow[t]{2}{*}{$\begin{array}{l}\text { A person's inclination to } \\
\text { reference a product }\end{array}$} & $\begin{array}{l}\text { I will refer Traveloka to } \\
\text { others. }\end{array}$ \\
\hline & & & $\begin{array}{l}\text { I would choose to use } \\
\text { Traveloka over other } \\
\text { similar applications. }\end{array}$ \\
\hline & $\begin{array}{l}\text { Exploration } \\
\text { Interest }\end{array}$ & $\begin{array}{l}\text { Interest behavior with } \\
\text { primary preference on } \\
\text { products }\end{array}$ & $\begin{array}{l}\text { I am interested in finding } \\
\text { information about } \\
\text { Traveloka. }\end{array}$ \\
\hline
\end{tabular}




\begin{tabular}{|c|c|c|c|}
\hline Variable & Dimension & Indicator & Statement \\
\hline \multirow{5}{*}{\begin{tabular}{l}
\multicolumn{1}{c}{ Price } \\
(Muharam and \\
Soliha, 2017)
\end{tabular}} & \multirow[t]{4}{*}{ Price Match } & \multirow[t]{3}{*}{$\begin{array}{l}\text { Price according to the } \\
\text { offer given }\end{array}$} & $\begin{array}{l}\text { The price of the product } \\
\text { sold is in line with my } \\
\text { expectations. }\end{array}$ \\
\hline & & & $\begin{array}{l}\text { The price of the product } \\
\text { offered is in accordance } \\
\text { with its quality. }\end{array}$ \\
\hline & & & $\begin{array}{l}\text { The price of the product is } \\
\text { affordable and in } \\
\text { accordance with the } \\
\text { quality offered. }\end{array}$ \\
\hline & & $\begin{array}{l}\text { Prices in accordance with } \\
\text { product benefits }\end{array}$ & $\begin{array}{l}\text { Prices offered are in } \\
\text { accordance with perceived } \\
\text { benefits. }\end{array}$ \\
\hline & $\begin{array}{l}\text { Competitive } \\
\text { prices }\end{array}$ & $\begin{array}{l}\text { Adapted to market } \\
\text { dynamics }\end{array}$ & $\begin{array}{l}\text { Product prices at } \\
\text { Traveloka compete with } \\
\text { other similar applications. }\end{array}$ \\
\hline \multirow{10}{*}{$\begin{array}{l}\text { Product Quality } \\
\text { (Lubis (2015) }\end{array}$} & \multirow[t]{3}{*}{ Application } & Available in the market & $\begin{array}{l}\text { Traveloka application is } \\
\text { very easy to get. }\end{array}$ \\
\hline & & Attractive product design & $\begin{array}{l}\text { The combination of color } \\
\text { and image content in } \\
\text { Mobile Apps and the } \\
\text { Website is very } \\
\text { interesting. }\end{array}$ \\
\hline & & Good use of language & $\begin{array}{l}\text { The language in the } \\
\text { Traveloka application is } \\
\text { easy to understand. }\end{array}$ \\
\hline & \multirow[t]{3}{*}{ Specifications } & $\begin{array}{l}\text { Appropriate } \\
\text { specifications provided }\end{array}$ & $\begin{array}{l}\text { Selection of existing } \\
\text { products has complete } \\
\text { specifications and types. }\end{array}$ \\
\hline & & \multirow[t]{2}{*}{$\begin{array}{l}\text { Meet predetermined } \\
\text { standards }\end{array}$} & $\begin{array}{l}\text { The choice of existing } \\
\text { transportation needs is in } \\
\text { accordance with the } \\
\text { traveling needs. }\end{array}$ \\
\hline & & & $\begin{array}{l}\text { Standard products offered } \\
\text { are good and recognized. }\end{array}$ \\
\hline & \multirow[t]{3}{*}{$\begin{array}{l}\text { Additional } \\
\text { Functions }\end{array}$} & $\begin{array}{l}\text { Features contained in an } \\
\text { application }\end{array}$ & $\begin{array}{l}\text { Additional functions } \\
\text { related to the location of } \\
\text { attractions, events, SPA, } \\
\text { and other entertainment } \\
\text { locations are useful for } \\
\text { me. }\end{array}$ \\
\hline & & \multirow[t]{2}{*}{ Application privileges } & $\begin{array}{l}\text { 1. Payment of bills and } \\
\text { data purchases are useful } \\
\text { added values. }\end{array}$ \\
\hline & & & $\begin{array}{l}\text { 2.Finding places to eat is } \\
\text { beneficial for me. }\end{array}$ \\
\hline & $\begin{array}{l}\text { Customer } \\
\text { Service (CS) }\end{array}$ & $\begin{array}{l}\text { Customer Service (CS) } \\
\text { skills in serving } \\
\text { consumers }\end{array}$ & $\begin{array}{l}\text { 1.CS is very informative } \\
\text { about the products offered }\end{array}$ \\
\hline
\end{tabular}




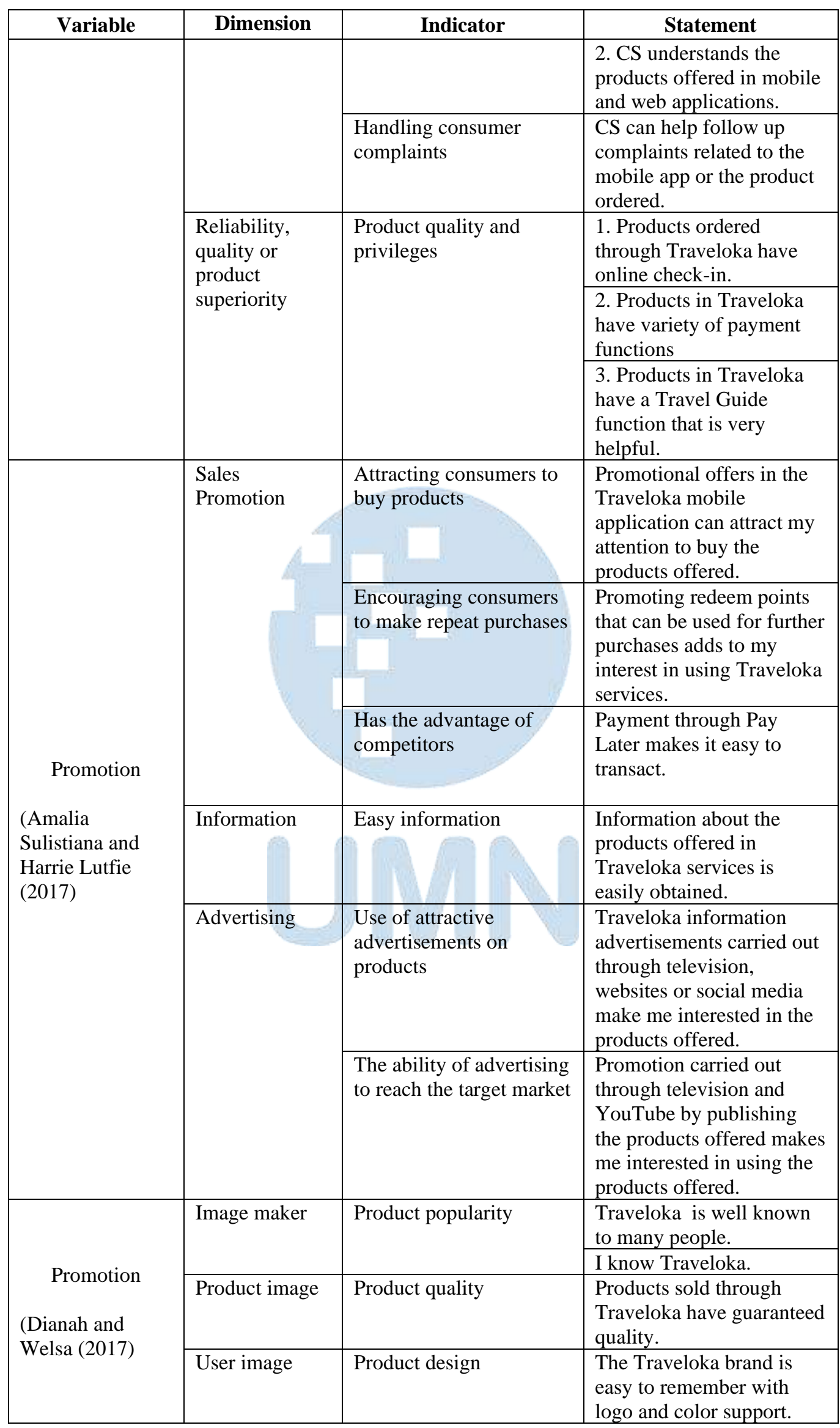




\begin{tabular}{|l|l|l|l|}
\hline Variable & Dimension & \multicolumn{1}{c|}{ Indicator } & \multicolumn{1}{c|}{ Statement } \\
\hline & & Brand advantages & $\begin{array}{l}\text { Traveloka brand is easy to } \\
\text { say. }\end{array}$ \\
\hline
\end{tabular}

\section{RESULTS AND DISCUSSION}

3.1 Outer model result

\subsubsection{Convergent validity result}

Table 2. Results of Respondents' Validity Test Scores

\begin{tabular}{|c|c|c|c|c|c|c|}
\hline Statement & Interest & Price & $\begin{array}{l}\text { Quality } \\
\text { Product }\end{array}$ & Promotion & $\begin{array}{l}\text { Brand } \\
\text { Image }\end{array}$ & $\begin{array}{l}\text { Purchase } \\
\text { Decision }\end{array}$ \\
\hline $\mathrm{X} 1.1$ & 0.840 & & & & & \\
\hline $\mathrm{X} 1.2$ & 0.872 & & & & & \\
\hline $\mathrm{X} 1.3$ & 0.557 & & & & & \\
\hline $\mathrm{X} 1.4$ & 0.873 & & & & & \\
\hline $\mathrm{X} 1.5$ & 0.837 & & & & & \\
\hline X1.6 & 0.762 & & & & & \\
\hline $\mathrm{X} 2.1$ & & 0.858 & & & & \\
\hline $\mathrm{X} 2.2$ & & 0.858 & $2=$ & & & \\
\hline $\mathrm{X} 2.3$ & & 0.841 & & 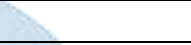 & & \\
\hline $\mathrm{X} 2.4$ & & 0.870 & & , & & \\
\hline $\mathrm{X} 2.5$ & & 0.767 & & & & \\
\hline X3.1 & & & 0.756 & & & \\
\hline X3.2 & & & 0.684 & & & \\
\hline X3.3 & & 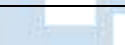 & 0.669 & & & \\
\hline X3.4 & & & 0.814 & & & \\
\hline X3.5 & & & 0.709 & & & \\
\hline X3.6 & & & 0.703 & & & \\
\hline X3.7 & & 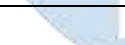 & 0.773 & 7 & & \\
\hline X3.8 & & & 0.746 & & & \\
\hline X3.9 & & & 0.773 & & & \\
\hline X3.10 & & & 0.799 & & & \\
\hline X3.11 & & & 0.778 & & & \\
\hline X3.12 & & & 0.722 & & & \\
\hline X3.13 & & & 0.729 & 18 & & \\
\hline X3.14 & & 7 & 0.794 & 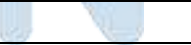 & & \\
\hline X3.15 & & & 0.644 & & & \\
\hline $\mathrm{X} 4.1$ & & & & 0.842 & & \\
\hline $\mathrm{X} 4.2$ & & & & 0.810 & & \\
\hline $\mathrm{X} 4.3$ & & & & 0.876 & & \\
\hline $\mathrm{X} 4.4$ & & & & 0.807 & & \\
\hline $\mathrm{X} 4.5$ & & & & 0.783 & & \\
\hline $\mathrm{X} 4.6$ & & & & 0.678 & & \\
\hline X5.1 & & & & & 0.850 & \\
\hline $\begin{array}{r}\times 5.2 \\
\end{array}$ & & & & & 0.879 & \\
\hline $\mathrm{X} 5.3$ & & & & & 0.876 & \\
\hline X5.4 & & & & & 0.862 & \\
\hline X5.5 & & & & & 0.697 & \\
\hline Y1 & & & & & & 0.842 \\
\hline $\mathrm{Y} 2$ & & & & & & 0.897 \\
\hline Y3 & & & & & & 0.930 \\
\hline Y4 & & & & & & 0.863 \\
\hline
\end{tabular}


Based on the Outer Loading Factor results above, there are several indicators that have a loading factor value of less than 0.6 and are not significant.

\subsubsection{Discriminant validity results}

Table 3. Results of Cross Loading Test for Respondent Validity

\begin{tabular}{|c|c|c|c|c|c|c|}
\hline Statement & Interest & Price & $\begin{array}{r}\text { Quality } \\
\text { Product }\end{array}$ & Promotion & $\begin{array}{l}\text { Brand } \\
\text { Image }\end{array}$ & $\begin{array}{l}\text { Purchase } \\
\text { Decision }\end{array}$ \\
\hline $\mathrm{X} 1.1$ & 0.840 & 0.517 & 0.532 & 0.447 & 0.529 & 0.646 \\
\hline $\mathrm{X} 1.2$ & 0.872 & 0.482 & 0.525 & 0.415 & 0.522 & 0.676 \\
\hline $\mathrm{X} 1.3$ & 0.557 & 0.237 & 0.128 & 0.132 & 0.233 & 0.375 \\
\hline $\mathrm{X} 1.4$ & 0.873 & 0.504 & 0.509 & 0.393 & 0.454 & 0.626 \\
\hline $\mathrm{X} 1.5$ & 0.837 & 0.572 & 0.609 & 0.506 & 0.538 & 0.737 \\
\hline X1.6 & 0.762 & 0.555 & 0.457 & 0.427 & 0.451 & 0.658 \\
\hline $\mathrm{X} 2.1$ & 0.539 & 0.858 & 0.613 & 0.527 & 0.458 & 0.554 \\
\hline $\mathrm{X} 2.2$ & 0.563 & 0.858 & 0.641 & 0.639 & 0.491 & 0.449 \\
\hline $\mathrm{X} 2.3$ & 0.483 & 0.841 & 0.554 & 0.600 & 0.391 & 0.410 \\
\hline $\mathrm{X} 2.4$ & 0.442 & 0.870 & 0.597 & 0.595 & 0.433 & 0.502 \\
\hline $\mathrm{X} 2.5$ & 0.544 & 0.767 & 0.587 & 0.475 & 0.480 & 0.561 \\
\hline X3.1 & 0.501 & 0.528 & 0.756 & 0.472 & 0.667 & 0.525 \\
\hline $\mathrm{X} 3.2$ & 0.452 & 0.466 & 0.684 & 0.449 & 0.481 & 0.446 \\
\hline X3.3 & 0.457 & 0.450 & 0.669 & 0.474 & 0.563 & 0.421 \\
\hline X3.4 & 0.617 & 0.647 & 0.814 & 0.617 & 0.628 & 0.585 \\
\hline $\mathrm{X} 3.5$ & 0.472 & 0.516 & 0.709 & 0.476 & 0.514 & 0.570 \\
\hline X3.6 & 0.534 & 0.533 & 0.703 & 0.586 & 0.460 & 0.570 \\
\hline X3.7 & 0.413 & 0.519 & 0.773 & 0.676 & 0.566 & 0.471 \\
\hline X3.8 & 0.430 & 0.511 & 0.746 & 0.585 & 0.623 & 0.480 \\
\hline X3.9 & 0.334 & 0.534 & 0.773 & 0.657 & 0.556 & 0.393 \\
\hline X3.10 & 0.479 & 0.600 & 0.799 & 0.611 & 0.474 & 0.527 \\
\hline $\mathrm{X} 3.11$ & 0.409 & 0.578 & 0.778 & 0.616 & 0.533 & 0.481 \\
\hline $\mathrm{X} 3.12$ & 0.318 & 0.466 & 0.722 & 0.575 & 0.429 & 0.433 \\
\hline X3.13 & 0.437 & 0.537 & 0.729 & 0.594 & 0.501 & 0.438 \\
\hline $\mathrm{X} 3.14$ & 0.409 & 0.575 & 0.794 & 0.619 & 0.608 & 0.449 \\
\hline X3.15 & 0.322 & 0.436 & 0.644 & 0.595 & 0.381 & 0.323 \\
\hline $\mathrm{X} 4.1$ & 0.428 & 0.569 & 0.610 & 0.842 & 0.522 & 0.505 \\
\hline $\mathrm{X} 4.2$ & 0.368 & 0.489 & 0.623 & 0.810 & 0.347 & 0.432 \\
\hline $\mathrm{X} 4.3$ & 0.442 & 0.623 & 0.702 & 0.876 & 0.517 & 0.533 \\
\hline $\mathrm{X} 4.4$ & 0.401 & 0.590 & 0.633 & 0.807 & 0.473 & 0.433 \\
\hline $\mathrm{X} 4.5$ & 0.362 & 0.520 & 0.562 & 0.783 & 0.442 & 0.400 \\
\hline $\mathrm{X} 4.6$ & 0.433 & 0.410 & 0.567 & 0.678 & 0.466 & 0.377 \\
\hline $\mathrm{X} 5.1$ & 0.546 & 0.447 & 0.615 & 0.446 & 0.850 & 0.535 \\
\hline X5.2 & 0.505 & 0.440 & 0.575 & 0.392 & 0.879 & 0.519 \\
\hline $\mathrm{X} 5.3$ & 0.493 & 0.483 & 0.596 & 0.487 & 0.876 & 0.497 \\
\hline X5.4 & 0.471 & 0.431 & 0.622 & 0.501 & 0.862 & 0.505 \\
\hline X5.5 & 0.422 & 0.465 & 0.616 & 0.608 & 0.697 & 0.442 \\
\hline Y1 & 0.737 & 0.485 & 0.581 & 0.428 & 0.492 & 0.842 \\
\hline Y2 & 0.691 & 0.527 & 0.592 & 0.534 & 0.542 & 0.897 \\
\hline Y3 & 0.728 & 0.513 & 0.555 & 0.483 & 0.589 & 0.930 \\
\hline Y4 & 0.640 & 0.599 & 0.576 & 0.548 & 0.490 & 0.863 \\
\hline
\end{tabular}

From the results above, all loading constructs in the intended construct are greater than the values of the other construct loading. Thus, it can be interpreted that all constructs have adequate discrimination. 


\subsection{Composite reliability results}

Table 4. Results of respondents

\begin{tabular}{|l|c|c|c|c|}
\hline \multicolumn{1}{|c|}{ Variable } & $\begin{array}{c}\text { Cronbach's } \\
\text { Alpha }\end{array}$ & rho_A & $\begin{array}{c}\text { Composite } \\
\text { Reliability }\end{array}$ & $\begin{array}{c}\text { Average Variance } \\
\text { Extracted (AVE) }\end{array}$ \\
\hline Interests & 0.882 & 0.901 & 0.912 & 0.636 \\
\hline Price & 0.895 & 0.900 & 0.923 & 0.705 \\
\hline Product Quality & 0.941 & 0.945 & 0.948 & 0.549 \\
\hline Promotion & 0.887 & 0.899 & 0.915 & 0.643 \\
\hline Brand Image & 0.890 & 0.895 & 0.920 & 0.699 \\
\hline Purchase Decision & 0.906 & 0.907 & 0.934 & 0.781 \\
\hline
\end{tabular}

In general, the value of composite reliability that can be used is at least 0.6 or more with Cronbach's alpha scores above 0.7. It can be concluded that the instrument used in this study is statistically reliable.

\subsection{Testing results (Inner Model)}

Testing the inner model or structural model is done to see the relationship between the construct, significance value, and R-square of the research model.

The structural model is evaluated using R-square for the dependent construct of the t-test as well as the significance of the coefficient of structural path parameters.

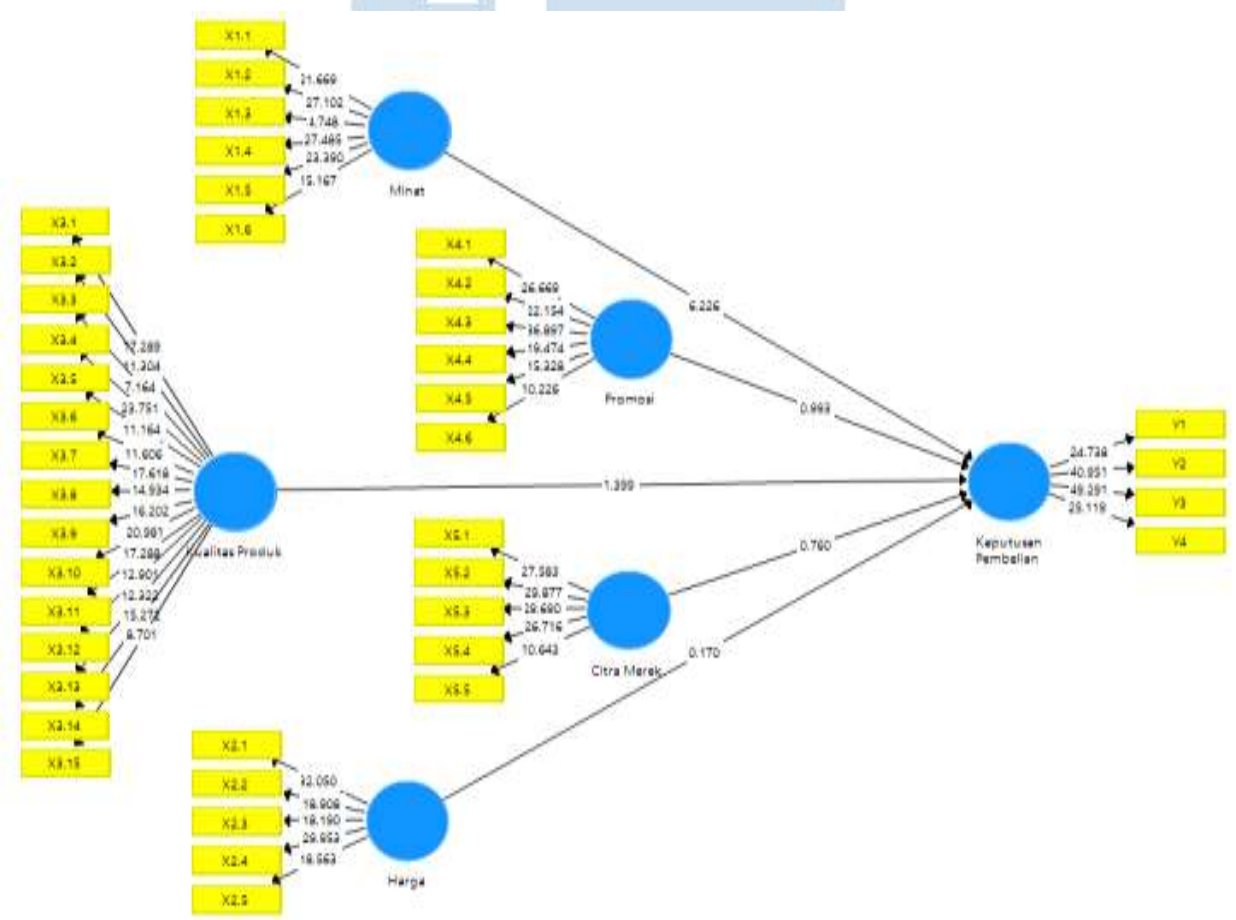

Figure 1. Model of Measurement

\subsection{R-Square}

Table 5. R-Square Respondent

\begin{tabular}{|c|r|r|}
\hline Variable & \multicolumn{1}{|c|}{ R Square } & \multicolumn{1}{c|}{ R Square Adjusted } \\
\hline Purchase Decision & 0.682 & 0.665 \\
\hline
\end{tabular}


Table 5 shows the R-square value for the purchase decision variable which obtained a value of 0.682 or $68.2 \%$ which means that the purchase decision variable can be influenced by the independent variable.

\subsection{Hypothesis test}

The basis used in testing the hypothesis is the value contained in the output result for inner weight.

Table 6. Effects between variables: Result for inner weights

\begin{tabular}{|l|r|r|r|r|r|}
\hline \multicolumn{1}{|c|}{ Effect } & \multicolumn{1}{c|}{$\begin{array}{c}\text { Original } \\
\text { Sample } \\
(\mathrm{O})\end{array}$} & $\begin{array}{c}\text { Sample } \\
\text { Mean } \\
(\mathrm{M})\end{array}$ & \multicolumn{1}{c|}{$\begin{array}{c}\text { Standard } \\
\text { Deviation } \\
(\text { STDEV })\end{array}$} & \multicolumn{1}{c|}{$\begin{array}{c}\text { T } \\
\text { Statistics } \\
(\mid \mathrm{O} / \text { STDEV })\end{array}$} & P Values \\
\hline $\begin{array}{l}\text { Interest -> } \\
\text { Purchasing Decision }\end{array}$ & 0.598 & 0.588 & 0.096 & 6.226 & $\mathbf{0 . 0 0 0}$ \\
\hline $\begin{array}{l}\text { Price -> } \\
\text { Purchasing Decision }\end{array}$ & 0.024 & 0.018 & 0.144 & 0.170 & $\mathbf{0 . 8 6 5}$ \\
\hline $\begin{array}{l}\text { Product Quality -> } \\
\text { Purchasing Decision }\end{array}$ & 0.158 & 0.171 & 0.113 & 1.399 & $\mathbf{0 . 1 6 2}$ \\
\hline $\begin{array}{l}\text { Promotion -> } \\
\text { Purchasing Decision }\end{array}$ & 0.078 & 0.073 & 0.078 & 0.993 & $\mathbf{0 . 3 2 1}$ \\
\hline $\begin{array}{l}\text { Brand Image -> } \\
\text { Purchasing Decision }\end{array}$ & 0.077 & 0.088 & 0.101 & 0.760 & $\mathbf{0 . 4 4 7}$ \\
\hline
\end{tabular}

\subsubsection{Hypothesis 1 Testing (Influence of Interest on Purchasing Decisions)}

The results of the first hypothesis testing able to show the relationship of interest to the purchase decision as presented in Table 11 showing the original value $(\mathrm{O})$ which is a path coefficient of 0.598 with a statistical T value of 6.226. This value is greater than the value of $t-$ table $(1,960)$. So it can be interpreted that Purchasing interest has a positive and significant influence on purchasing decisions.

\subsubsection{Hypothesis 2 Testing (Effect of Prices on Purchasing Decisions)}

The results of the second hypothesis testing show the relationship of prices to purchasing decisions as presented in Table 11 showing the original value $(\mathrm{O})$ which is a path coefficient of 0.024 with a statistical $t$ value of 0.170 . This value is smaller than the table value $(1,960)$. So it can be interpreted that the price does not significantly influence the purchase decision.

\subsubsection{Hypothesis 3 Testing (Effect of Product Quality on Purchasing Decisions)}

The results of the third hypothesis testing show the relationship on product quality to purchasing decisions as presented in Table 11 showing the original value $(\mathrm{O})$ which is a path coefficient of 0.158 with a statistical $t$ value of 1.399 . This value is smaller than the table value $(1,960)$. So the values show product quality does not significantly influence purchasing decisions.

\subsubsection{Hypothesis 4 Testing (Effect of Promotion on Purchasing Decisions)}

The fourth hypothesis testing results show the relationship of promotion to purchase decisions as presented in Table 11 showing the original value $(\mathrm{O})$ which is a path coefficient of 0.078 with a statistical $t$ value of 0.993 . This value is smaller than the $t$ table value $(1,960)$. 
So it can be interpreted that the promotion does not significantly influence the purchase decision.

\subsubsection{Hypothesis 5 Testing (Effect of Brand Image on Purchasing Decisions)}

The fifth hypothesis testing results show the relationship of brand image to the purchase decision as presented in Table 11 showing the original value $(\mathrm{O})$ which is a path coefficient of 0.077 with a t value of 0.760 statistics. This value is smaller than the table value $(1,960)$. So it can be interpreted that the brand image has no significant effect on purchasing decisions.

\subsection{Discussion}

\subsubsection{Influence of Interest on Purchasing Decisions}

Based on the results of the hypothesis test and discussion of the data that have been carried out, it is obtained from the results of the study that there is a positive and significant influence on purchasing decisions. Consumer interest in a product is influenced by the knowledge held and information from the product or service. Consumers who are interested on the product will search for positive information about the product after they hear the brand of the product. In addition, a good perception about the quality of the product will stimulate the emergence of buying interest which impact on the urge to make a purchase decision.

Number of downloads and users of Traveloka applications and similar applications in the period 2018 - Q1 2019 is the following: (TravelsPromo, 2019).

1. Traveloka has been installed in more than 10 million devices. With a very good average application score, it reaches 4.4 out of more than 300,000 users.

2. Tiket.com has been downloaded by more than 5 million users, with an average application assessment of 4.2 from 36,000 more users.

3. Nusatrip has been downloaded and installed on more than 100,000 devices with an application value of 4.4 from over 1000 users.

4. Pegipegi has been installed on more than $1,000,000$ android devices with an application value of 4.5 out of 50,000 more users.

5. EzyTravel is currently not installed on many devices with only 5,000 users, as well as getting the application value is quite low with only 3.8 out of 100 more users.

Five airplane and hotel ticket booking sites with 2018 visitors according to Similar web data: (Cekaja.com, 2018).

1. Traveloka: November 2018, 15.75 million visitors with a total of 39.18 million

2. Tiket.com: November 2018, 5.56 million visitors with a total of 8.90 million

3. Booking.com: A total 3.97 million visitors

4. Pegipegi.com: A total of 2.97 million visitors

5. Agoda: A total of 2.40 million visitors

\subsubsection{Effect of Price on Purchasing Decisions}

Based on the results of the hypothesis test and the discussion of the data that has been done, it was discovered that the price does not significantly influence the purchase decision. Price becomes an important factor in consumer purchasing decisions, especially if the price 
offered is affordable and in accordance with the quality of the product so that it can hit the hearts of consumers. Prices cannot be used as a benchmark for consumers in making purchasing decisions, and some of the reasons are because the price offered does not match the perceived benefits, the price of the product is not affordable, and the price does not match the quality offered.

List of consumer choices for purchasing airline ticket applications at affordable prices:

(TravelsPromo, 2019).

Cheap holiday season flight tickets for the top 5 traveling apps, namely:

1. Nusatrip;

2. Ezytravel;

3. Pegi-pegi;

4. Tiket.com; and

5. Traveloka.

Cheap low season flight tickets for the top 5 traveling apps, namely:

1. Nusatrip;

2. Ezytravel;

3. Tiket.com;

4. Pegi-pegi; and

5. Traveloka.

\subsubsection{Effect of Product Quality on Purchasing Decisions}

Based on the results of the hypothesis test and the discussion of the data that has been carried out, it was discovered that the quality of the product has no significant effect on purchasing decisions. The quality of a product is important and the main thing for consumers who will make a purchase decision for a product. If the quality of the product is low, consumers will be hesitant to buy the product. Besides that, other causes underlying why consumers are reluctant to make a purchase decision can be due to the additional functions contained in the Traveloka application which do not all support the traveling needs of consumers, and can cause damage (error) related to the mobile app or the product ordered by the consumer.

Based on the data from Similarweb (2020), the comparison of Traveloka applications with similar applications on Top Google Play Apps in Indonesia, Travel and Local, Top Free, is as follows:

- Traveloka: Being in order number 2

- Tiket.com: Being in sequence number 3

- Reddorz: Being in number 4

- Pegipegi.com: Was at number 9

- Agoda.com: Is at number 10

- Airy: Being in order number 13

- Booking.com: Is at number 18

- Trivago: Was at number 25

- NusaTrip: Is at number 30

- Mister Aladin: Being in sequence number 40

\subsubsection{Effect of Promotion on Purchasing Decisions}

Based on the results of the hypothesis test and the discussion of the data that has been done, it was discovered that promotion does not have a significant effect on purchasing decisions. Promotion will affect purchasing decisions if the promotion is able to provide and 
fulfill the basic functions of the promotion and it introduces and generates consumer confidence in the product. Promotions conducted on social media and print media should be able to encourage purchasing decisions. However, with all promotions carried out by consumers, they do not conform with product promotion because consumers accept promotions with nonquality performance. Bad behavior for purchases will be given by consumers despite evaluations of alternative purchases.

Based on the findings of Alvara Research Institute in 2019, "Traveloka is said to have many promos. On the other hand, Tiket.com is in demand because it is easier to use. (Tirto.id, 2019).

\subsubsection{Effect of Brand Image on Purchasing Decisions}

Based on the results of the hypothesis test and the discussion of the data that has been carried out, it was observed that the brand image has no significant effect on purchasing decisions. Brand image is the impression received by the public about a product. A brand image that feels good has a much better chance of being bought than a product that has an unpleasant or neutral image. Brand image that cannot influence consumers to make purchasing decisions explains that brand image cannot be an additional reference for potential customers and does not take into consideration the desired product. The Traveloka brand is already widely known to the public and it can be said to have a good brand image, so that the public is no longer considering making a purchase decision. For consumers, a good brand image may not necessarily make them want to buy or try the product. Some consumers consider other things, for example product quality, friend recommendations, or in accordance with their own desires.

The Traveloka brand is already well known by the public. This is indicated by Traveloka being the top in the minds of the respondent traveling application with a figure of 79.8 percent. This figure dominates other applications: Tiket.com (8.9 percent), Blibli.com (5.6 percent), and KAI Access (3.2 percent). (CNNIndonesia, 2019).

Referring to the startup ranking site, Traveloka is ranked third in the top startups in Indonesia. In early 2019 Traveloka entered Australia through the application and website. Besides that, despite already having a lot of fitus, Traveloka continues to innovate to develop its services both through applications and websites (Wartakotalive.com, 2019).

\section{CONCLUSION}

Based on the research results of several variables tested, the following conclusions can be drawn:

1. Interest has a positive and significant influence on purchasing decisions in the Traveloka application. The emergence of interest in consumers to buy or use the services offered by Traveloka will encourage consumers to determine purchasing decisions on products offered by Traveloka.

2. Price does not significantly influence the purchase decision in the Traveloka application. This shows that the price of Traveloka is relatively expensive and not affordable by respondents with "middle to lower" income so that respondents do not make a purchasing decision.

3. Product quality has no significant effect on purchasing decisions in the Traveloka application. Demands on the quality of a product that has become a necessity cannot be met by the company, causing consumers who have owned to switch to competing products that are considered to have better product quality.

4. Promotion has no significant effect on purchasing decisions in the Traveloka application. Not all promotional offers in the Traveloka application can attract the 
attention of consumers, and do not make consumers tempted to buy products offered on the Traveloka application.

5. Brand image has no significant effect on purchasing decisions in the Traveloka application. Not all consumers make purchasing decisions based on recognition or knowledge of a brand image that is already known or is being talked about, because some consumers usually make a purchase decision based on several things such as quality, price or will from within themselves.

\section{References}

Astuti, R., \& Abdullah, I. (2017). "Pengaruh Kualitas Produk dan Promosi terhadap Keputusan Pembelian Pakaian di Usaha Mikro Kecil Menengah”. Jurnal Ilman, Vol. 5, No. 2, 1423.

Dewi, N.S., \& Prabowo, R.E. (2018). "Performa Kualitas Produk, Persepsi Harga, Promosi, dan Gaya Hidup Dalam Mempengaruhi Proses Keputusan Pembelian Minuman Isotonik (Studi Konsumen Minuman Isotonik Di Kota Semarang)". Jurnal Administrasi Bisnis, Volume 5 Nomor 1, 710-716.

Dianah, N., \& Welsa, H. (2017). "Pengaruh Kualitas Produk dan Citra Merek Terhadap Keputusan Pembelian Smartphone Xiaomi Serta Dampaknya Pada Kepuasan Konsumen (Studi Kasus pada Mahasiswa Fakultas Ekonomi Universitas Sarjanawiyata Tamansiswa”. Jurnal Manajemen, Vol 7, No 1, 16-26.

Hendro, C.., \& Hidayat, W. (2018). "Pengaruh Kualitas Produk, Harga dan Citra Merek Terhadap Keputusan Pembelian Konsumen Handphone Merek Iphone Kota Semarang". Diponegoro Journal Of Social and Politic, 1-8.

Kurniawati, D dkk. (2014). "Pengaruh Citra Merek dan Kualitas Produk Terhadap Kepuasan dan Loyalitas Pelanggan (Studi pada Pelanggan KFC Cabang Kawi Malang)". Jurnal Administrasi Bisnis (JAB), Vol. 14 No. 2, 1-9.

Lubis, A.A. (2015). "Pengaruh Harga dan Kualitas Produk Terhadap Keputusan Pembelian Surat Kabar Pada PT. Suara Barisan Hijau Harian Orbit Medan". Jurnal Ilmiah Manajemen dan Bisnis, Vol. 16, No. 02, 1-11.

Muharam, W., \& Soliha, E. (2017). "Kualitas Produk, Citra Merek, Persepsi Harga dan Keputusan Pembelian Konsumen Honda Mobilio". Proceeding SENDI_U, 755-762.

Riyono., \& Budiharja, G.E. (2016). "Pengaruh Kualitas Produk, Harga, Promosi dan Brand Image Terhadap Keputusan Pembelian Produk Aqua Di Kota Pati". Jurnal STIE Semarang, Vol 8, No 2, 92-121.

Sari, R.L dkk. (2014). "Citra Merek, Harga dan Promosi Pengaruhnya Terhadap Keputusan Pemebelian Perhiasan Emas Pada PT. Pegadaian (Persero) Cabang Manado Utara”. Jurnal EMBA, Vol.2 No.2, 1222-1232.

Satria, D.A., \& Sidharta, H. (2017). "Pengaruh Citra Merek dan Kualitas Produk Terhadap Minat Beli Konsumen Porkball". PERFORMA: Jurnal Manajemen dan Start-Up Bisnis Volume 2, Nomor 3, 398-408.

Sulistiana, A., \& Lutfie, H. (2017). "Pengaruh Advertising dan Citra Merek Terhadap Keputusan Pembelian Pada Fashion Hijab Elzatta Di Kota Bandung Tahun 2017 (Studi Kasus Konsumen Elzatta Bandung)". e-Proceeding of Applied Science, Vol.3, No.2, 593599. 
Widyaningrum, N.A. (2017). "Dampak Bauran Pemasaran Terhadap Minat Beli Konsumen Pada Produk Crispy Rice Crackers". PERFORMA: Jurnal Manajemen dan Start-Up Bisnis, Volume 1, Nomor 6, 634-641.

https://tekno.kompas.com/read/2019/05/16/03260037/apjii-jumlah-pengguna-internet-diindonesia-tembus-171-juta-jiwa

https://travelspromo.com/promo-tiket-pesawat/aplikasi-tiket-pesawat/

https://www.cekaja.com/info/5-situs-penyedia-layanan-tiket-paling-banyak-dikunjungisepanjang-2018/

https://www.similarweb.com/apps/top/google/store-rank/id/travel-and-local/top-free https://tirto.id/traveloka-lebih-banyak-digunakan-milenial-ketimbang-tiketcom-edXE https://www.cnnindonesia.com/teknologi/20190709195545-185-410676/aplikasi-ecommerce-dan-online-travel-pilihan-milenial

https://wartakota.tribunnews.com/2019/06/24/ini-7-daftar-startup-teratas-indonesiabukalapak-tempati-ranking-pertama?page $=4$
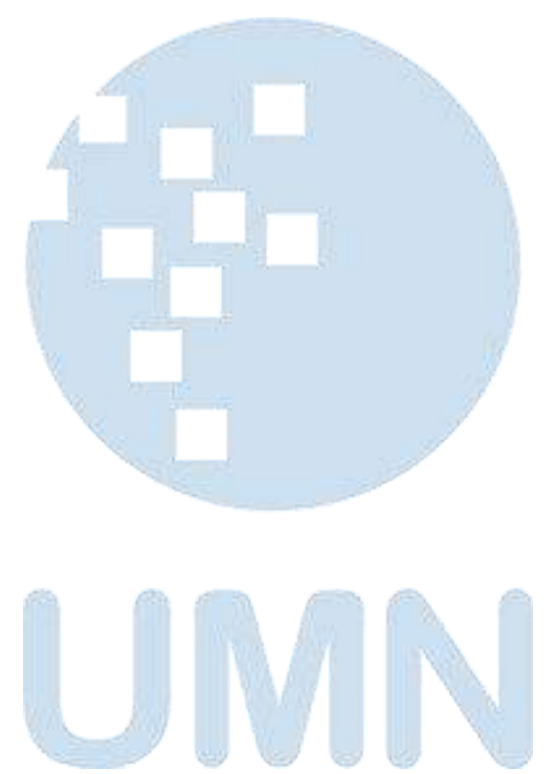